\title{
ENTERPRISE RISK MANAGEMENT PADA CLOUD COMPUTING
}

\author{
Samudera Dipa Legawa ${ }^{1}$ \\ Universitas Muhammadiyah Tangerang / Fakultas Teknik, \\ Program Studi Informatika \\ Jl. Perintis Kemerdekaan 1/33 Cikokol Kota Tangerang TLP. 55793251, 55772949, 55793802, 55736926 \\ e-mail: dipa@raharja.info
}

\begin{abstract}
ABSTRAK
Kemajuan teknologi informasi telah mengubah cara pengolahan informasi yang tadinya berupa mainframe ke komputer pribadi hingga ke komputasi berbasis web.Saat ini, banyak organisasi serius mempertimbangkan untuk mengadopsi teknologi cloud computing, Cloud computing (komputasi awan) merupakan gabungan pemanfaatan teknologi komputer (komputasi) dalam suatu jaringan dengan pengembangan berbasis internet (awan) yang mempunyai fungsi untuk menjalankan program atau aplikasi melalui komputer - komputer yang terkoneksi pada waktu yang sama. Akan tetapi penerapan cloud computing itu sendiri memunculkan beragam resiko, apalagi layanan cloud computing menggunakan pihak ketiga atau outsourcing. Oleh karena itu perlu ada manajemen resiko yang tepat dalam mengidentifikasi, menilai, dan memitigasi resiko terkait penerapan cloud computing. Pada makalah ini, telah berhasil dirancang sebuah model manajemen resiko pada penerapan cloud computing berdasarkan framework COSO Enterprise Risk Management (ERM).
\end{abstract}

Kata kunci: Teknologi Informasi, Cloud Computing, Manajemen Resiko

\begin{abstract}
Advances in information technology have changed the way of processing information who used to be a mainframe to personal computers to the web-based computing. Today, many organizations are seriously considering adopting cloud computing technology, Cloud computing is the combined use of computer technology in a network with the development of Internet-based (cloud) which has the function to run a program or application via a computer - a computer connected at the same time. However, the application of cloud computing itself led to various risks.
\end{abstract}

Keywords: Information Technology, Cloud Computing, Risk Management

\section{Pendahuluan}

Pada musim gugur 2010, seorang eksekutif Google bersaksi di depan sub komite Kongres AS bahwa lebih dari tiga juta bisnis di seluruh dunia adalah pelanggan dari penawaran layanan awan. Gartner Inc memprediksi bahwa komputasi awan akan menjadi industri $\$ 140.000 .000 .000$ pada tahun 2014. Kemajuan teknologi dalam virtualisasi sistem, manajemen sumber daya sistem, dan Internet telah menyebabkan munculnya komputasi awan sebagai alternatif untuk memenuhi kebutuhan teknologi dari berbagai jenis perusahaan, dengan manfaat sebagai berikut beresonansi dengan para eksekutif:

1. Pemenuhan sumber daya komputasi Seketika

2. Nilai yang lebih besar dari pengeluaran teknologi dengan biaya rendah

3. Platform teknologi umum yang dapat memfasilitasi standardisasi, dan 
4. Berkurangnya kebutuhan personil dukungan teknologi dalam negeri.

Seperti halnya peluang baru, komputasi awan membawa resiko yang sepadan. Ini membawa kepada organisasi dimensi yang berbeda dari kolaborasi dan interaksi manusia, ketergantungan organisasi baru, pemenuhan sumber daya lebih cepat, dan model bisnis baru. Komite Sponsoring Organizations of (COSO) Enterprise Risk Management Komisi Treadway - Kerangka Terpadu menetapkan bahasa yang umum dan pondasi bagi organisasi untuk menilai dan mengawasi resiko dari perspektif holistik. Mengutip pernyataan abadi dibuat dalam publication bahwa: "Manajemen resiko perusahaan memungkinkan manajemen untuk secara efektif menangani ketidakpastian dan resiko yang terkait dan kesempatan, meningkatkan kapasitas untuk membangun nilai." Cloud computing bisa menghadirkan perubahan yang signifikan terhadap lingkungan operasi, penggunaan Enterprise COSO Manajemen Resiko Kerangka Terpadu akan memfasilitasi identifikasi resiko dan strategi mitigasi dengan paradigma komputasi awan berkembang yang menyajikan peluang yang signifikan serta ketidakpastian. Tujuan dari publikasi ini adalah untuk memanfaatkan prinsip-prinsip Enterprise Risk Management COSO - Kerangka Terpadu dalam rangka memberikan pedoman yang akan mengidentifikasi singkat resiko dan dampak komputasi awan akan memiliki pada suatu organisasi. Para eksekutif lebih menjadi mengerti tentang resiko dan manfaat dari komputasi awan, semakin efektif mereka akan dapat mempersiapkan organisasi mereka untuk masa depan. Pedoman yang disajikan di sini akan memungkinkan para eksekutif untuk mengidentifikasi, memantau, dan mengurangi atau menerima resiko yang datang dengan menggunakan komputasi awan.

\section{Pembahasan}

\subsection{Pengertian Cloud Computing}

Untuk dapat memahami tentang cloud computing dimulai dengan memahami pengertian cloud computing. Ada banyak definisi yang tersedia tentang cloud computing yang diberikan para ahli dan organisasi. Namun sebagian besar merujuk pada definisi yang dikemukakan oleh NIST. NIST (National Institute of Standards Technology) memberikan definisi tentang cloud computing sebagai sebuah model untuk memungkinkan ketersebaran, kenyamanan dan akses jaringan berdasarkan permintaan pada sebuah sumber daya komputasi yang telah dikonfigurasi bersama (misalnya, jaringan server, penyimpanan, aplikasi dan layanan) yang dapat dengan cepat dirilis dengan upaya manajeman yang minimal atau interaksi dengan penyedia layanan. Sedangkan Kantor Komisaris Privasi Canada (The Office of Privacy Commissioner of Canada) menjelaskan Cloud computing adalah penyediaan layanan komputasi melalui Internet. Layanan Cloud memungkinkan individu dan bisnis untuk menggunakan perangkat lunak dan perangkat keras yang dikelola oleh pihak ketiga secara remote (jarak jauh). Contoh layanan awan meliputi penyimpanan online berkas, situs jejaring sosial, webmail, dan aplikasi bisnis online.

Sementara itu Garry Conway (2011) menjelaskan bahwa komputasi awan, secara umum, adalah sesuatu yang memberikan layanan host TI melalui Internet, dan memungkinkan konsumen untuk mengakses layanan dan data melalui perangkat dengan Akses Internet. Apa yang membedakan komputasi awan dari komputasi tradisional adalah bahwa: layanan cloud dijual atas permintaan; fleksibel (pengguna dapat mengkonsumsi sebanyak atau sesedikit yang mereka butuhkan); dan Layanan dikelola oleh provider [8]. Istilah ini berasal dari metafora untuk internet yang secara mendasar adalah jaringan dari jaringan yang memberikan akses secara jarak jauh (remote) ke sekumpulan (set) sumber daya IT yang terdesentralisasi.

Dengan demikian dapatlah dipahami bahwa cloud computing adalah sebuah model jaringan computer(computer network), tersebar di mana-mana, yang dapat diakses melalui internet dan akses berdasarkan permintaan (fleksibel/elastis), memiliki sumber daya komputasi dan telah dikonfigurasi untuk penggunaan secara 
bersama-sama (shared) baik untuk jaringan server, penyimpanan data atau layanan aplikasi, yang dapat disediakan dengan cepat atau melalui interaksi dengan penyedia layanan.

\subsection{Karakteristik Cloud Computing}

Karakteristik adalah segala sesuatu yang menjadi ciri khas, dalam hal cloud computing yang menjadi karakteristiknya sebagaimana di ungkapkan oleh NIST. berikut ini adalah karakeristik dasar cloud computing merujuk pada penjelasan NIST dan kemudian diikuti oleh penjelasan para ahli lainnya:

\section{A. On demand Self Service :}

Pengguna dapat secara sepihak menentukan kapabilitas komputasi, seperti menentukan waktu server, jaringan penyimpanan sesuai yang diperlukan secara otomatis tanpa berinteraksi dengan manusia pada setiap penyedia jasa layanan, yaitu, konsumen dapat dilayani secara otomatis dapat meminta layanan berdasarkan kebutuhan mereka, tanpa interaksi manusia dengan penyedia layanan. Atau dengan kata lain pengguna dapat berlangganan hanya yang dia butuhkan saja, dan membayar hanya untuk yang mereka gunakan saja. Misalkan sebuah sebuah internet service provider menyediakan 5 macam pilihan atau paketpaket internet dan user hanya mengambil 1 paket internet maka user hanya membayar paket yang diambil saja.

\section{B. Broad network access}

NIST menjelaskan karakteristik ini sebagai kemampuannya menyediakan akses jaringan melalui mekanisme-mekanisme standar yang memajukan penggunaan berbagai platform baik thin client maupun thick client (misalnya ponsel, tablet, laptop dan workstation). Sedangkan Komunitas Cloud Computing Indonesia menjelaskan sebagai kapabilitas layanan dari cloud provider tersedia lewat jaringan dan bisa diakses oleh berbagai jenis perangkat, seperti smartphone, tablet, laptop, workstation, dsb. Secara ringkas dapat dikatakan kemampuan Cloud (Hardware dan software) yang tersedia melalui jaringan dan diakses melalui berbagai platform.

\section{Resource Pooling.}

Sumber daya pelayanan di kumpulkan dalam satu tempat untuk melayanai berbagai pelanggan dengan menggunakan model multi layanan, dengan fisik dan sumber daya virtual yang berbeda secara dinamis ditugaskan dan ditugaskan kembali sesuai permintaan pelanggan. Ada sebuah rasa independensi lokasi yang secara umum pelanggan tidak memiliki kontrol atau pengetahuan melalui lokasi yang senyatanya dari sumberdaya provider, tetapi mungkin sanggup menentukan lokasi pada level abstraksi yang lebih tinggi (misalnya negara, provinsi atau pusat data). Sebagai contoh sumber daya termasuk storage (media penyimpanan), pemroses, memory dan bandwith. M.Hamdaqa dan L.Tahvildari (2012) menyebut karakeristik ini sebagai Resource Pooling and Multi Tenancy, yaitu sumber daya cloud seperti storage, memory, bandwitdh dan virtual machine, dipakai bersama oleh multi pelanggang dan ditugaskan secara eksklusif untuk sementara waktu berjalan pada satu pengguna dalam satu waktu (bersamaan). Penugasan sumberdaya dilakukan secara dinamis berdasarkan pada kebutuhan pelanggan.

\section{Rapid Elasticity}

Kapabilitas dapat secara lentur (elastis) ditetapkan dan di rilis, pada beberapa kasus dapat secara otomatis, untuk skala keluar masuk secara cepat sepadan dengan permintaan. Untuk pelanggan ketersediaan kapabilitas untuk menyediakan yang sering muncul menjadi tidak terbatas dan dalam setiap kuantitas dapat disesuaikan setiap waktu.

\section{E. Measured Service}

Sistem cloud secara otomatis mengkontrol dan mengoptimalkan penggunaan sumber daya dengan memanfaatkan kemampuan pengukuran pada beberapa tingkat penyesuaian secara abstrak pada macammacam layanan (seperti storage,pemrosesan, bandwidth dan akun pengguna aktif). Pemakaian sumber daya dapat dipantau, dikendalikan dan dilaporkan secara transparan untuk kedua penyedia layanan dan pelanggan atas penggunaan layanan. 
Karakteristik di atas berdasarkan pada kondisi yang tersedia saat ini, dan masih sangat mungkin untuk berkembang pada masa yang akan datang.

\subsection{Resiko dan Manajemen Resiko}

Resiko memiliki arti yang bermacam-macam sesuai konteks yang dirujuk atau sudut pandang yang digunakan. HM Treasury mendefinisikan resiko sebagai ketidakpastian dari suatu hasil, apakah peluang positif atau ancaman (threat) negatif dari aksi maupun kejadian. Resiko harus dapat dinilai mematuhi kombinasi dari semua kemungkinan dari hal yang akan terjadi dan dampak yang

akan muncul bila hal tersebut terjadi. Stoneburner dkk (2002) menyebutkan bahwa resiko adalah dampak negatif yang diakibatkan dengan adanya kerentanan (vulnerability), berdasarkan pertimbangan dari probabilitas maupun dampak kejadian. Dari beberapa pengertian yang telah disebutkan, resiko dapat diartikan sebagai dampak negatif dari suatu ancaman yang mengeksploitasi kerentanan yang apabila terjadi, akan merugikan. Resiko terkait TI merupakan adalah suatu pengukuran kuantitatif dari kerugian atau kerusakan yang disebabkan oleh ancaman (threat), vulnerability, atau oleh suatu kejadian (event: malicious atau non malicious) yang berpengaruh pada kumpulan aset $\mathrm{TI}$ yang dimiliki oleh organisasi.

\subsection{COSO ERM}

COSO mendefinisikan Enterprise Risk Management (ERM) sebagai proses yang dipengaruhi oleh entitas dewan direksi, manajemen dan personil lainnya, diterapkan pada pengaturan strategi dan di seluruh perusahaan yang dirancang untuk mengidentifikasi peristiwa potensial yang dapat mempengaruhi entitas, dan mengelola resiko untuk tetap berada pada risk appetitenya, untuk memberikan keyakinan yang memadai mengenai pencapaian tujuan entitas. Framework COSO ERM merupakan kubus 3-dimensi, selain sisi depan yang terdiri dari 8 komponen, sisi atas merupakan objektif manajemen resiko dan sisi samping kubus merupakan komponen entitas. ERM versi COSO terdiri dari 8 komponen yang saling terkait, yaitu: Lingkungan Internal (Internal Environment), Penetapan Tujuan (Objective Setting), Identifikasi Kejadian (Event Identification), Penilaian Resiko (Risk Assessment), Respon Resiko (Risk Response), Aktivitas Pengendalian (Control Activities), Informasi dan komunikasi (Information and Communication), Pemantauan (Monitoring).

\subsection{ERM Pada Cloud Computing}

Munculnya komputasi awan harus dipertimbangkan sebuah acara di lingkungan operasi program ERM organisasi.

Seperti usaha apapun, menentukan tujuan dan program tindakan di muka meningkatkan peluang keberhasilan. Akibatnya, rencana berkembang dengan baik yang jelas mendefinisikan tujuan organisasi dan spesifik peran cloud computing akan memungkinkan manajemen untuk membuat keputusan yang tepat. Beberapa prasyarat ERM yang harus menjadi faktor dalam rencana mutu komputasi awan, dan akhirnya solusi cloud adalah model yang kuat pemerintahan, struktur pelaporan suara, pemahaman yang akurat tentang kemampuan IT internal dan kemampuan, dan risk appetite yang ditetapkan .

Beberapa tim manajemen melihat penilaian resiko dan program pemerintahan sebagai opsional. Hal ini tidak biasa bagi organisasi untuk mengadopsi solusi komputasi awan tanpa menerapkan evaluasi resiko formal maupun pengeluaran setiap usaha untuk menyesuaikan ERM nya atau program pemerintahan. Ini adalah praktek terbaik untuk

menggabungkan tata awan pada tahap awal ( ketika strategi komputasi awan sedang didefinisikan ) sebelum solusi cloud diadopsi . Untuk organisasi yang sudah mengadopsi komputasi awan tanpa mengikuti praktik ERM terbaik, masih bijaksana untuk melakukan penilaian resiko dan membangun tata kelola awan . 
Dalam kasus dimana solusi cloud telah dilaksanakan, kerangka ERM COSO dapat digunakan untuk membangun, memperbaiki, atau melakukan pemeriksaan jaminan kualitas dari program tata kelola awan dengan memastikan bahwa semua aspek utama dari program ( misalnya , tujuan, penilaian resiko, dan respon resiko ) telah ditangani sehubungan dengan persyaratan manajemen. Sebuah program tata kelola awan yang efektif masih dapat dicapai dengan menerapkan kerangka ERM COSO setelah pelaksanaan solusi cloud.

Situasi praktek terbaik adalah ketika manajemen menggunakan kerangka ERM COSO untuk mengidentifikasi konfigurasi yang ideal pilihan solusi cloud (yaitu, proses bisnis, model penyebaran, dan model pengiriman layanan ) yang sesuai dengan risk appetite manajemen . Dengan mengevaluasi kandidat solusi cloud dalam konteks masing-masing komponen dari kerangka ERM COSO, manajemen singkat dapat mengidentifikasi resiko yang terkait dan strategi penerimaan resiko atau mitigasi yang diinginkan dengan setiap skenario solusi cloud (sebagai resiko akan bervariasi dengan masing-masing kombinasi pilihan). Evaluasi ini akan memungkinkan manajemen untuk melakukan manajemen resiko dan tata kelola keputusan yang bijaksana dalam memilih set yang ideal pilihan solusi cloud dan menciptakan program pemerintahan awan

\section{REFERENSI}

[1] Ahmed Mohamed Gamaleldin "An Introduction to Cloud Computing Concepts" Software Engineering Competence Center 2013

[2] Alex Budiyanto Komunitas "Pengantar Cloud Computing"Cloud Computing Indonesia 2012

[3] Alexa Huth and James Cebula "The Basics of Cloud Computing" Carnegie Mellon University 2011

[4] Berkah I. Santoso," Cloud Computing dan Strategi TI Modern" Komunitas Cloud Computing Indonesia, 2012

[5] Cisco "Cisco Cloud Computing -Data Center Strategy, Architecture, and Solutions Point of View White Paper dipikirkan dengan baik - out- sebelum solusi cloud diimplementasikan .Bahan sisa bagian ini menguraikan beberapa konsep kunci sehubungan dengan mengevaluasi kandidat solusi cloud melalui masing-masing komponen dari kerangka COSO ERM : Lingkungan internal - Komponen lingkungan internal berfungsi sebagai dasar untuk mendefinisikan dan risk appetite organisasi dalam hal bagaimana resiko dan kontrol yang dilihat. Misalnya, jika manajemen memiliki kebijakan Tidak Outsourcing salah satu operasi (yaitu ada budaya penghindaran resiko), kebijakan ini akan membatasi pilihan yang layak untuk penyebaran awan dan layanan model pengiriman sehingga solusi awan swasta mungkin satu-satunya alternatif yang dapat diterima.

\section{Kesimpulan}

Manajemen perlu mengevaluasi bagaimana komputasi awan sejalan dengan tujuan organisasi. Tergantung pada keadaan, komputasi awan mungkin memberikan kesempatan bagi organisasi untuk meningkatkan kemampuannya untuk mencapai tujuan yang ada, atau mungkin memberikan kesempatan untuk mendapatkan keuntungan kompetitif , yang akan membutuhkan tujuan baru yang akan ditetapkan.

[6] Cloud $U$ "Understanding the Cloud Computing Stack: PaaS, SaaS, laaS" Diversity Limited, 2011

[7] Crowe Horwath, "Enterprise Risk Management for Cloud Computing" COSO Juni 2012

[8] David Chappell "A short Introduction into Cloud Platform, an Enterprise Oriented View", David Chappell and Asosiated 2008 